\title{
Mechanisms of decomposition of hydrocarbons in electrical discharges
}

\author{
D.I. Slovetsky \\ Institute of Petrochemical Syntheses, Academy of Sciences of USSR, Moscow, V-71

\begin{abstract}
The mechanisms of decomposition of hydrocarbons in electric discharge plasmas are discussed, with special reference to: (i) plasma parameter measurements, (ii) composition of stable and unstable chemically active particles, (1i1) mechanisms of lonization, excitation and decomposition including solid polymeric products generated by nonequilibrlum chemical kinetics.
\end{abstract}

\section{INTRODUCTION}

Much work has been published on the study of the decomposition of hydrocarbons in nonequilibrium electrical discharges in which gaseous and solld polymeric products are generated, e.g. Innear and cyclic saturated and unsaturated hydrocarbons and aromatic compounds. The dependence of outputs in stable products on external discharge parameters such as pressure, gas-flow rate and electric power - have been used in the past to elucidate mechanisms of chemical reactions. The method using small accepting admixtures, applied successfully in the past for studying reactions in photo- and radiation chemistry, have not been so successful in the case of plasmas because (i) they may give a large varlation of internal plasma parameters; and (ii) known radical or ion acceptors may have the opposite effect due to decomposition, Ionization or excitation.

Analogy of plasmachemical product composition with photochemical, radiochemical or mass-spectrometrical ones was used in interpretation also. But this way is not informative because of large variation of product composition with plasma parameters and complexity of chemical conversations with participation of electrons, radicals, excited particles and negative and positive ions.

Chemical reactions in nonequilibrium cold plasmas are initiated, as a rule, by collisions of molecules with electrons having large energy taken from electrical field immediately. Many particles having large chemical activity are generated by electron molecule collisions such as electronically and vibrationally exclted molecules, negative and positive ions and radicals (ref. 1). Simultaneously some stable products may be generated. All particles may take part in following collisions with electrons, molecules, and one with another, giving secondary reactions. Heavy particles energy is low if the gas temperature is low. But by large specific power of discharge it may be large enough to give thermal pyrolysis reaction (Fig. 1,2). In addition, due to electron-molecule primary collisions hot atoms and radicals may be generated which are very active in chemical reactions even at low gas temperature.

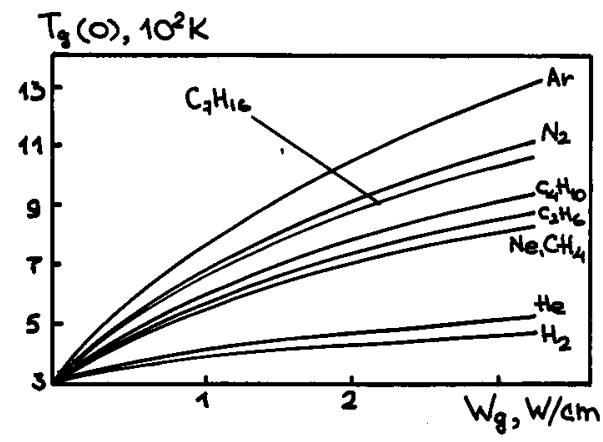

Fig. 1. Gas temperatures on the axis of discharge through some gases in tubular reactor versus specific power at $\mathrm{T}_{\mathrm{g}}(R)=$ $300 \mathrm{~K}$.

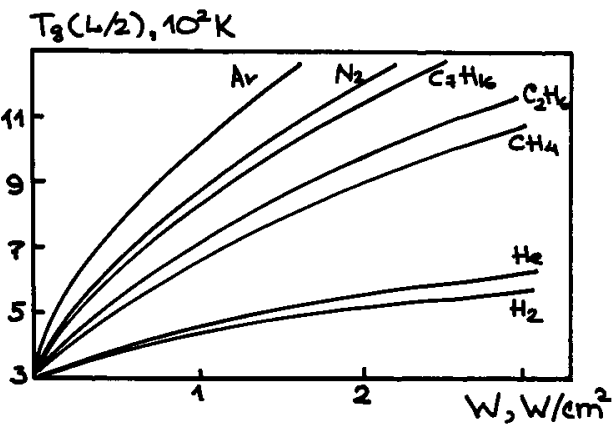

Fig. 2. Gas temperatures at the midale line between parallel plate electrodes in diod type reactor versus specific power with $I=2 \mathrm{~cm}, R \gg I$ at electrodes $\mathrm{T}=\mathrm{P}_{\mathrm{g}}(0)=\mathrm{T}_{\mathrm{g}}(\mathrm{I})=300 \mathrm{~K}$. 
Due to this reason the chemical reaction mechanism in nonequilibrium plasma may be very complex and dependent on internal plasma parameter range. It is necessary to note that determination of active particles, giving main contribution in product generation is difficult because of the various type of active particles there are in any electrical discharges through any gases but not all of them are important in chemistry.

Hence it is necessary for the plasmachemical reaction study to use the method of choice of most probable mechanisms of chemical reactions and physical processes in nonequilibrium plasmas (ref. 1). The method is based on the quantitative study of generation and decay kinetics of any particles in the frame of nonequilibrium chemical kinetic theory (ref. 2 ). To realize the method in practice is is desirable to have measurements of all internal plasma parameters which influence the direction and rate of the chemical reactions (Table 1).

TABLE 1. Discharge parameters and intrenal plasma parameters wich are necessary to know for mechanisms studying in nonequilibrium plasmas

Parameters Measuring technique

\section{Discharge parameters :}

$\begin{array}{ll}\text { Power , W W } & \text { Electrotechnical devices } \\ \text { Electrical current, I, } \mathrm{mA} & \\ \text { Electrical field strength, } & \\ \text { E, V/cm } & \text { Probes } \\ \text { Gas pressure, }, \mathrm{Pa} & \text { Membrane or capacitive manometers } \\ \text { Gas flow rate, G, } \mathrm{cm}^{3} / \mathrm{s} & \text { Volume gas flow meter }\end{array}$

Internal plasma parameters

\section{Energy of particles :}

Electron energy distribution function (EEDF), $f_{e}\left(E_{e}\right)$

Heavy particle (gas) temperature, $\mathrm{T}_{\mathrm{g}}, \mathrm{K}$

Rotational temperature of molecules, $T_{\text {rot }}, K$

Vibrational temperature or distribution function of vibrational level populations

\section{Particle densities :}

Electrons, $\mathrm{n}_{\mathrm{e}}$

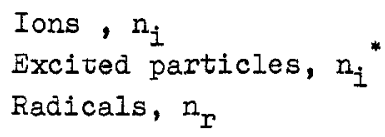

lotal heavy partical densiety, No
Electrical probes, optical spectroscopy Doppler broadening of spectral Ines Optical spectroscopy, laser incluced, Raman spectroscopy Thermoprobes, thermocouples, 
Review of the works concerning hydrocarbon chemical reactions under discharge conditions shows insufficient knowledge of plasma parameters. In many cases even external parameters, such as specific electric power, are not reported. Investigations were carried out using various reactor constructions and discharge types - direct current, high frequency and microwave discharges. Without internal plasma parameters having been measured it is difficult to compare the results of various workers and to make objective conclusions about mechanisms of chemical reactions.

More detalled studies were performed using direct current discharge through mixtures of rare gases with methane and $\mathrm{C}_{5}-\mathrm{C}_{7}$ - hydrocarbons (ref. 3-15). The internal plasma parameters, radical and stable product compositions were measured. Variation of hydrocarbon contents and discharge current makes it possible to study kinetic order of reactions. Important results were obtained by means of labeled isotopic techniques which allow to discriminate the products of primary decay from products of the secondary one.

This lecture is based on the results of plasma parameter measurements and composition of stable and unstable chemically active particles. Mechanisms of ionization, excitation and hydrocarbon decomposition are discussed including generation of gaseous and solid polymeric products by means of nonequilibrium chenical kinetics.

\section{PLASMA PARAMETERS, IONIZATION AND EXCITATION MECHANISMS}

Plasma parameters are best studied in positive column of direct current glow discharges through rare gases (ref. 1). But addition of small concentrations of hydrocarbons to rare gases gives large variation of electric field strength, mean electron energy and density (Fig. 3). Most sharp variations are observed at additions of $\alpha=0,01-0,05 \% c-\mathrm{C}_{6} \mathrm{H}_{12}$. At further increases of $\alpha$ from 0,05 to $2 \%$, the variations are smaller and plasma parameters are nearly constant in this range. Decreasing the electrical field strength results in hydrocarbons having ionization potential lower than excitation potential of the rare gas metastable atomic levels. When the electric field strength is increased ( $r e f .1,3,4,6$ ) the result is opposite. In more typical former case, gas temperature is lowered due to high heat transfer coefficient of hydrogen generated as a decomposition product and due to the decrease in electric field and specific power. To reduce electric field, $E / N_{O}$ is decreased as a result. Addition of hydrocarbons to rare gases decreases fast electron density even if $\mathrm{E} / \mathrm{N}_{\mathrm{O}}$ is constant (ref. 8-10). Both effects decrease coefficients of processes initiated by electron impacts and electron drift velocity. Electron density is increased to compensate decrease of drift velocity and to naintain constant electric current.

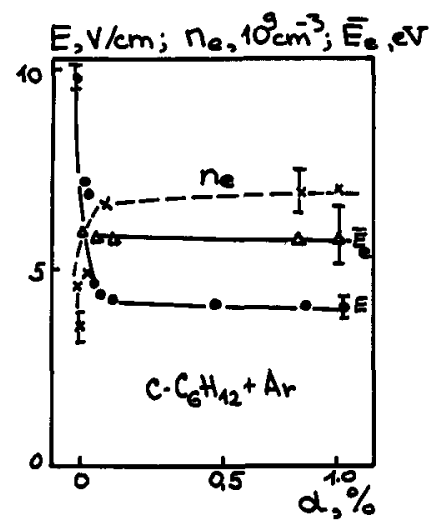

Fig.3. Effect of addition of small concentrations of hydrocarbons to rare gases in d.c. glow discharges - on electric field strength, mean electron energy and density.

Ionization rate must increase to give larger electron density in spite of decrease of electric field. Therefore, ionization mechanisms by hydrocarbon addition are varied. Ionization proceeds in glow discharge through pure rare gas under sufficient high current density $\left(j>1 \mathrm{~mA} / \mathrm{cm}^{2}\right)$ by a stepwise path: excitation of metastable atomic levels by electron impacts followed by ionization of metastable atoms by second electron impacts (ref. $1,6)$. Metastable levels excitation rate is decreased due to hydrocarbon addition and netastable atom densities are lowered due to decrease of density of fast electrons and quenching by hydrocarbon molecules. At very small additions $(\alpha \leq 0,001 \%)$ quenching is low compared to the electron impact $(<5 \%)$. However, the electric field strength is already decreased (Fig. 3). It is connected with contribution of Penning ionization occuring by collisions of metastable rare atoms with hydrocarbon molecules. The greater the hydrocarbon addition, the larger is molecular quenching and when $\alpha=1 \%$ its rate is at hundred times larger than quenching of metastables by electrons. Metastable densities are at hundred times less than the ones in rare gases. As a result the rates of stepwise processes of ionization and upper atomic levels excitation are decreased. This effect gives observable quenching of luminosity of discharge when hydrocarbons are added. 
On addition of cyclohexane to argon more than $0,01 \%$ main ionization process is Penning ionization having efficiency which is equal to $0,56 \pm 0,3$ per collision. Direct ionization of hydrocarbon molecules by electron impact gives contribution only at larger additions.

The process is main in pure hydrocarbon discharges where the electric field strength is increased again. The reason of this increase, is deficiency of fast electrons in its energy distribution which is the more the more are additions.

If the ionization potential of hydrocarbons is larger than excitation energy of rare gas met:astable level (for example, methane has $\mathbb{E}_{i o n}=12,5 \mathrm{eV}$, and argon $E_{m}=11,55 \mathrm{eV}$ ) electric field strength is increased by small extent because of decrease of stepwise ionization due to quenching of metzastable atoms which is not compensated by appearance of new ionization channel (ref. 1,15).

Penning ionization was used in (ref. 11) to explain the slow changing of electric field with time in discharge through mixtures of $\mathrm{Ar}$, He and Ne with benzene $(\alpha=0,1 \%)$. But characteristic time of the variation was equal to ten secondswhich is much more than the survival time of metrastable atoms varying from $10^{-3} \mathrm{~s}$ in pure rare gases to $10^{-5} \mathrm{~s}$ in mixtures. Hence this explanation is not correct. It is more probable that slow variations of electric field as observed are forced by chemical reactions, occuring particulary at reactor walls.

Small variation of plasma parameters in mixtures of rare gases with $0,1-2 \%$ hydrocarbons allow to study kinetic order of reaction depedending on hydrocarbon concentrations. Indepedence of plasma parameters on gas residence time in discharge $\left(\tau>10^{-3} \mathrm{~s}\right)$ gives possibility to carry out kinetic studying with simple interpretation. Influence of by - electrode regions on the chemical reactions was excluded by freezing of products in by - electrode zones (ref. 5-7).

\section{MECHANISMS OF DISSOCIATION OF HYDROCARBONS}

Dissociation rates of cyclohexane as measured are increased according to linear-low with increase of hydrocarbon concentration in mixture with argon, increased monotonically depedending on current density and gas pressure and independent o gas residence time in discharge within error limits (Fig. 4). This independence allow to exclude the reverse reaction of cyclohexane generation from dissociation products. This conclusion was confirmed by experiments with use of mixtures of protonated and deuterated cyclohexanes $(1: 1$ and 1:10) in argon. In this case products do not contain isotopic mixed cyclohexanes.

It was shown by evaluation of reaction rates of all energetically possible reactions that the main contribution in cyclohexane dissociation may give collisions with electrons, metsastable argon atoms and hot hydrogen atoms :

$$
\begin{aligned}
& c-\mathrm{C}_{6} \mathrm{H}_{12}+\mathrm{e} \rightarrow \mathrm{e}+\text { neutral products, } \\
& \mathrm{c}-\mathrm{C}_{6} \mathrm{H}_{12}+\mathrm{Ar}_{\mathrm{m}} \longrightarrow \operatorname{Ar}\left(\mathrm{C}_{0}\right)+\text { neutral products, } \\
& \mathrm{c}-\mathrm{C}_{6} \mathrm{H}_{12}+\mathrm{H}^{*} \longrightarrow \text { products }
\end{aligned}
$$

Hot hydrogen atoms $\left(\mathrm{H}^{*}\right)$ may be generated due to primary dissociation processes $(1,2)$ via decay of highly electronically excited molecules of cyclohexane. Hot atoms dissipate their energy during collisions with argon atoms be- 
fore collision with hydrocarbon molecules (3). Hence reaction probability depends on hydrocarbon concentration in mixture. Upper limit of reaction (3) rate can not be more than rate of hot atoms generation in reactions $(1,2)$, because in every act of reaction (3) hot atom must disappear. Therefore contribution of reaction (3) can in better case only enlarge the dissociation rate by factor two. It is the case if the every act of reactions $(1,2)$ gives appearance of hot atom and every hot atom gives disappearance of cyclohexane molecule in reaction (3). But really contribution of this reaction in hydrocarbon dissociation evidently is not so large because the dissociation rate is directly proportional to cyclohexane concentration in mixtures as observed (Fig. $4^{\mathrm{a}}$ ).
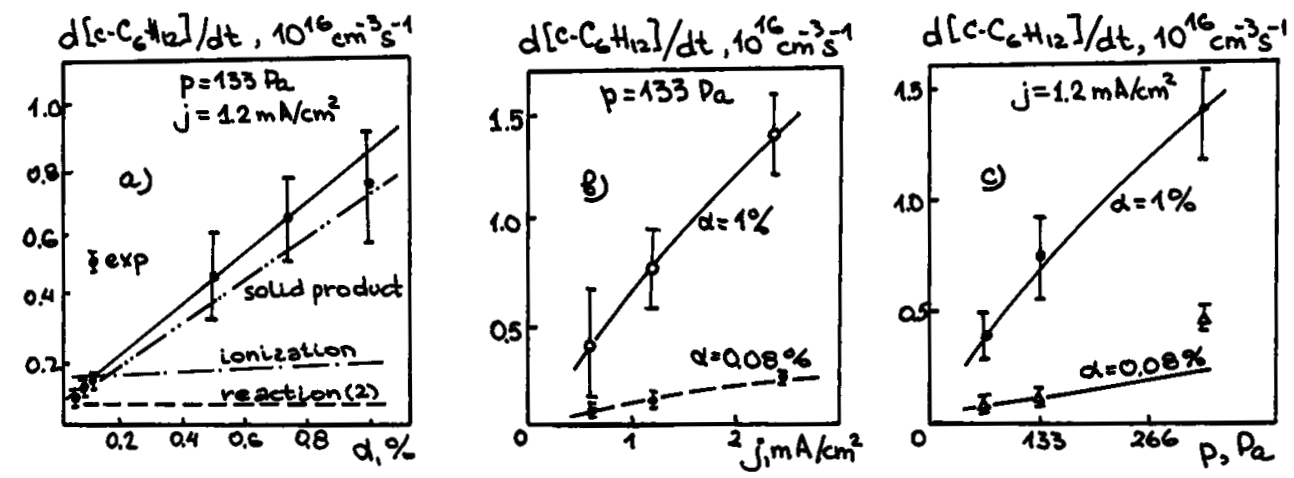

Fig. 4. Dissociation rates of cyclohexane versus its addition to argon in mixture (a), discharge current density (b) and gas pressure (c) with $R=0,5 \mathrm{~cm} ; G=390 \mathrm{~cm}^{3} / \mathrm{s}$. Iines are relative dependences calculated: 1 - due to reaction 1,2 - 2; 3 - ionization rate of cyclohexane due to collisions with argon methastable atoms; 4 - rate of solid products generation determined from $C$-atom balance. Points are dissociation rate measured

Taking into account the excitation and deexcitation of metastable argon atoms

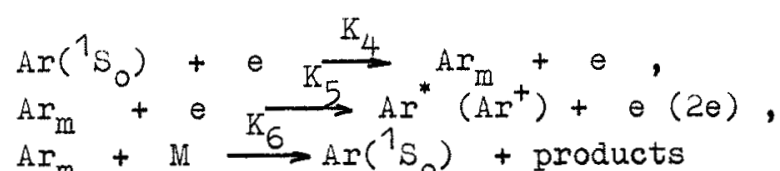

the reaction (2) rate equals

$$
j_{2}=\frac{\mathrm{K}_{2}\left[\mathrm{c}-\mathrm{C}_{6} \mathrm{H}_{12}\right] \mathrm{K}_{4} \cdot \mathrm{n}_{e}[\mathrm{Ar}]}{\mathrm{K}_{6}[\mathrm{M}]+\mathrm{K}_{5} \mathrm{n}_{e}}-\frac{h_{\mathrm{D}} \mathrm{K}_{4} \cdot \mathrm{n}_{e}[\mathrm{Ar}]}{1+\mathrm{K}_{5} \mathrm{n}_{\mathrm{e}} / \mathrm{K}_{6}[\mathrm{M}]}
$$

In expression (7) probability of dissociation due to molecular quenching (2, 6) is introduced

$$
\sum_{D}=K_{2} / K_{6}
$$

Also it is taken into account that molecular quenching is large compared with rare atom one, and cyclohexane dissociation degree is small. Then using the rate coefficients values $\mathrm{K}_{5}=(4,5 \pm 1,5) \cdot 10^{-17} \mathrm{~cm}^{3} \mathrm{~s}^{-1} ; \mathrm{K}_{6}=10^{-9} \mathrm{~cm}^{3} \mathrm{~s}^{-1}$ (ref. 13,14 ) and $\alpha \geqslant 0,5 \%$ ( $\alpha$ is relative concentration of cyclohexane in initial mixture) it can $\alpha^{\text {se }}$ shown that reaction (2) rate is not dependent on $\mathcal{\alpha}$ as ratio $\mathrm{K}_{5} \mathrm{n}_{\mathrm{e}} / \mathrm{K}_{6}\left[\mathrm{C}-\mathrm{C}_{6} \mathrm{H}_{12}\right]=5 \cdot 10^{3} \alpha \leq 0,1$ and electron density and energy are constant in the range $0,1 \%=\alpha=2 \%$ (Fig. 3). Rate of the reaction (3) must be 
directly proportional to $\alpha$. As follows from data of $\mathrm{Hig}$. 4 , reaction (3) gives main contribution in the range $0,1 \% \leq \alpha \leq 2 \%$. The reaction (2) contribution is significant only if $\alpha \leq 0,1 \%$.

The same dissociation rates were observed for other $\mathrm{C}_{5}-\mathrm{C}_{7}$ hydrocarbons under same conditions (Table 2). Reduced electric field is the same too for various hydrocarbons excluding benzene. Hence possibility of Penning-ionization by collisions of metaastable argon atoms with the hydrocarbons is nearly constant. For benzenevalue of $E / N_{0}$ is enlarged, which connected with diminishing of Penning-ionization probability due to appearance of additional channels such as intermolecular conversion of excitation energy.

TABL 2. Steps and rates of decomposition of number hydrocarbons in glow discharge through theire mixtures with argon under the same conditions: $j=2,4 \mathrm{~mA} / \mathrm{cm}^{2} ; p=133 \mathrm{~Pa}$; $\alpha_{\mathrm{C}_{\mathrm{H}} \mathrm{y}}=1 \% ; \mathrm{d}_{\text {tube }}=1 \mathrm{~cm}$ (ref. 4,5$)$

\begin{tabular}{lcccc}
\hline Hydrocarbon & $\begin{array}{l}\text { Legree of } \\
\text { dissocia- } \\
\text { tion, } \%\end{array}$ & $\begin{array}{l}\text { Residence } \\
\text { time, } t, \\
10^{-3} \mathrm{~s}\end{array}$ & $\begin{array}{l}\text { Dissociation } \\
\text { rate, } \mathrm{cm}^{-3} \mathrm{~s}^{-1}\end{array}$ & $\begin{array}{l}\text { Reduced electric } \\
\text { field, } \mathrm{E} / \mathrm{N}_{0} \\
10^{-16} \mathrm{~V} \cdot \mathrm{cm}^{\circ}\end{array}$ \\
\hline $\mathrm{c}^{-\mathrm{C}_{6} \mathrm{H}_{12}}$ & $15 \pm 2$ & 3,4 & $14 \pm 2$ & 1,2 \\
$c-\mathrm{C}_{5} \mathrm{H}_{10}$ & $12 \pm 2$ & 4,2 & $9,0 \pm 1,4$ & 1,2 \\
$c-\mathrm{C}_{6} \mathrm{H}_{11} \mathrm{CH}_{3}$ & $7 \pm 3$ & 3,4 & $6,5 \pm 2,6$ & 1,1 \\
$\mathrm{C}_{6} \mathrm{H}_{14}$ & $10 \pm 2$ & 4,5 & $7,1 \pm 1,3$ & 1,2 \\
$\mathrm{C}_{6} \mathrm{H}_{6}$ & $12 \pm 2$ & 4,2 & $9,0 \pm 1,4$ & 1,7 \\
\hline
\end{tabular}

The small variation of dissociation rates mean the approximate equality of dissociation cross-sections under electron - hydrocarbon collisions. This conclusion is confirmed by calculation of cross - sections of dissociation via excitation of optically allowed electronic transtions by electron - molecular impacts (Fig. 5) (ref. 15). The dissociation rates as calculated using this cross - section and electron energy distribution as calculated for pure argon plasmas (ref. 10) are significantly lower than measured ones (Fig. 6). This discrespancy may be explained by contribution of excitation of optically inallowed electronic transitions which is main process for the hydrocarbons as was shown in the past for the methane, ethane, propane and butane ( $r e f .16$ ). The same dissociation mechanism including stage (1-3) was observed for mixture of methane with rare gases (ref.6).

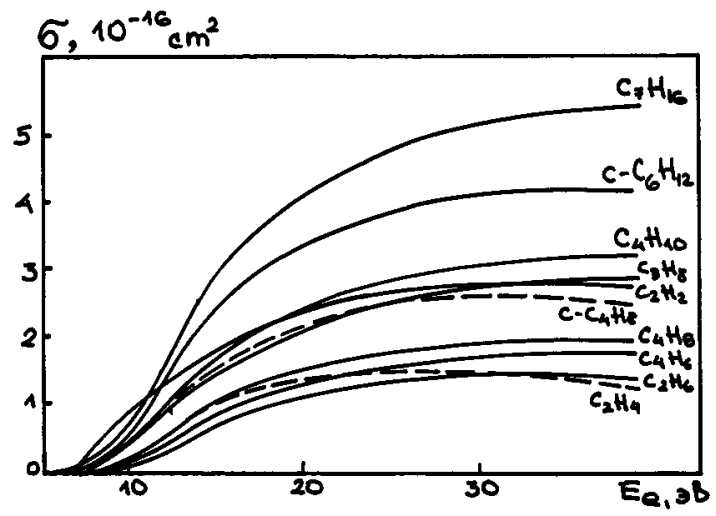

Fig. 5. Cross sections of hydrocarbons dissociation by electron impackts followed by excitation of optically allowed electronic transitions 


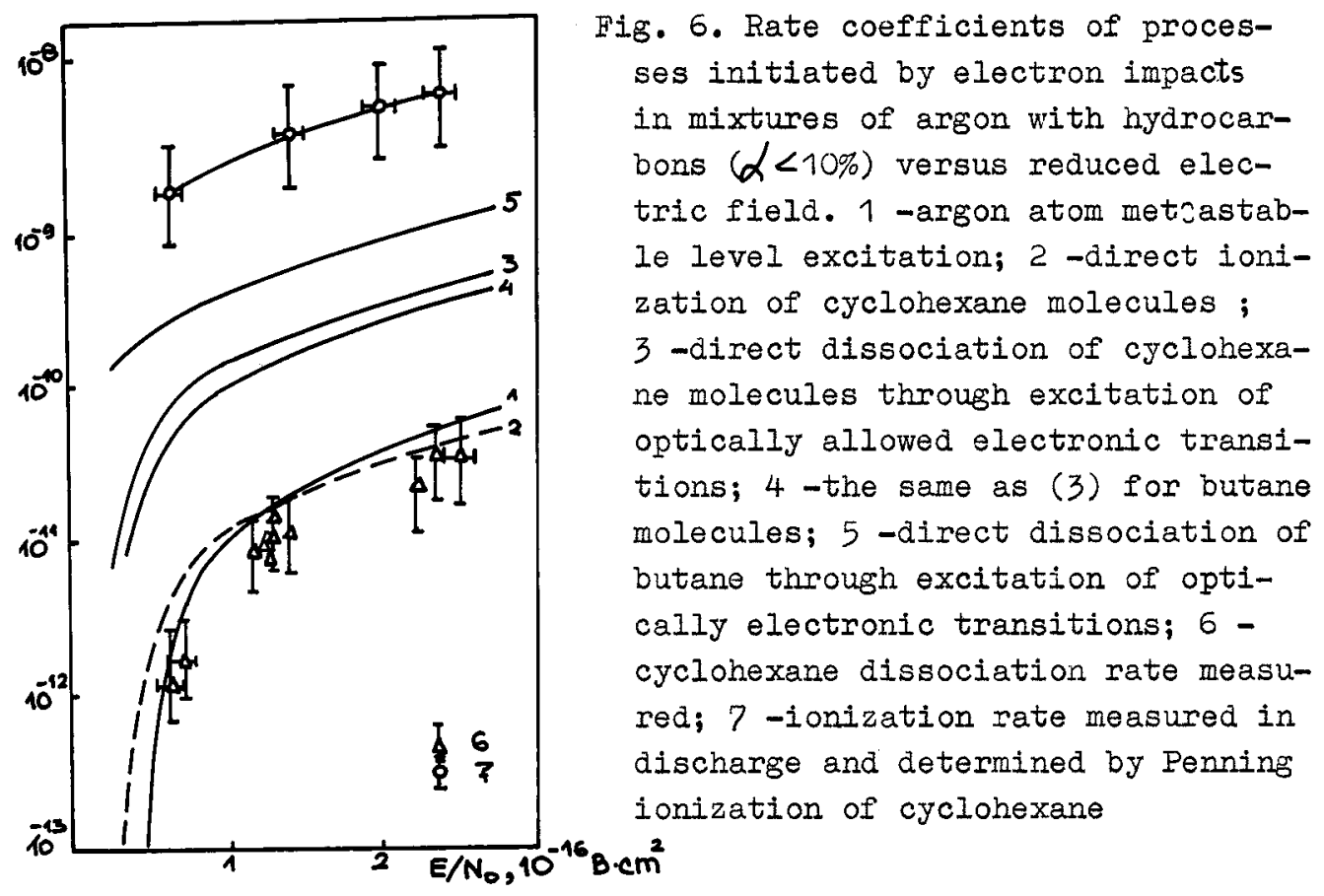

Thus initiation of hydrocarbons decomposition under nonequilibrium plasma conditions in mixtures with rare gases is due to collisionof molecules with fast electrons and excited metzastable rare atoms. Direct dissociation by electron impacts gives main contribution beginningfrom small additives (a few tenth of percent) up to 100\% hydrocarbons. Radicals generated due to primary decay do not cause chain processes at low gas temperatures $\left(T_{B}=\right.$ $500-600 \mathrm{~K})$. The dissociation rate can be twice due to influence of hot atoms and radicals generated during primary decay. The same dissociation mechanisms must be observed for hydrocarbons in other types of discharges such as $H F$ and MW under the same range of parameters: $\bar{E}_{e} \geq 1,5-2 \mathrm{eV} ; x_{e}=n_{e} / N_{0}<10^{-5}$; $\mathrm{T}_{8}<600 \mathrm{~K}$.

Variation of dissociation mechanism is possible due to enlarged gas heating at high specific discharge power (Fig. 1,2), when the radical reactions may give chains. In (ref. 17) it was supposed that increasing dissociation rates of number hydrocarbons as observed was caused by contribution of reactions with participation of vibrationally excited molecules without discussion of gas heating effects. This supposition seems to be impossible because of high efficiency of hydrocarbon vibrational relaxation (ref. 18).

\section{MECHANISMS OF GENERATION OF STABLE GASEOUS PRODUCTS}

Solid polymeric films are the main product of $\mathrm{C}_{4}-\mathrm{C}_{6}$ hydrocarbon decomposition in direct current discharge through mixtures of argon with hydrocarbons. The films are deposited on the reactor walls, electrodes and samples inserted to plasma ( $T a b l e ~ 3)$. Gaseous products composition of $\mathrm{c}_{6} \mathrm{C}_{12}$ dissociation in mixture with argon is nearly the same that one in pure $\mathrm{c}_{-} \mathrm{C}_{6} \mathrm{H}_{12}$ ( Table 4, culomns 2,3). But change of discharge type from dc to $\mathrm{HF}$ and $\mathrm{MW}$ discharge through methylcyclohexane gives variation of gaseous product composition and ratio of outputs of gaseous and solid products (Table 4, coIumns 8-10). 
TABLE3. Outputs of gaseous and solid products of hydrocarbons decomposition in discharges through mixtures with argon (ref.4,5)

\begin{tabular}{lcccc}
\hline Hydrocarbon & $\alpha_{\mathrm{C}_{\mathrm{x}} \mathrm{H}_{\mathrm{y}}} \%$ & Discharge & $\begin{array}{c}\text { Sum of gaseous } \\
\text { products }\end{array}$ & $\begin{array}{c}\text { Sum of solid } \\
\text { products }\end{array}$ \\
\hline $\mathrm{c}-\mathrm{C}_{6} \mathrm{H}_{12}$ & 100 & $\begin{array}{c}\text { Constant current } \\
\text { glow, } \mathrm{p}=133 \mathrm{~Pa}\end{array}$ & - & observed \\
$\mathrm{c}-\mathrm{C}_{6} \mathrm{H}_{12}$ & 1,0 & $-"-$ & 12 & 88 \\
$\mathrm{c}-\mathrm{C}_{5} \mathrm{H}_{10}$ & 1,0 & $-"-$ & 14 & 86 \\
$\mathrm{C}_{6} \mathrm{H}_{14}$ & 1,0 & $-"-$ & 38 & 62 \\
$\mathrm{C}_{6} \mathrm{H}_{6}$ & 1,0 & $-"-$ & 9 & 91 \\
$\mathrm{C}_{4} \mathrm{H}_{10}$ & 1,0 & $-"-$ & - & observed \\
$c-\mathrm{C}_{6} \mathrm{H}_{11} \mathrm{CH}_{3}$ & 1,0 & $-"-$ & 29 & 71 \\
$\mathrm{c}-\mathrm{C}_{6} \mathrm{H}_{11} \mathrm{CH}_{3}$ & 100 & High frequency(HF) & 79 & 21 \\
$\mathrm{c}-\mathrm{C}_{6} \mathrm{H}_{11} \mathrm{CH}_{3}$ & 100 & Microwave (MW) & 93 & 7 \\
\hline
\end{tabular}

TABIE 4. Main stable products of number hydrocarbons decomposition in electrical discharges (sum of gaseous product without hydrogen is equal to 100\%)

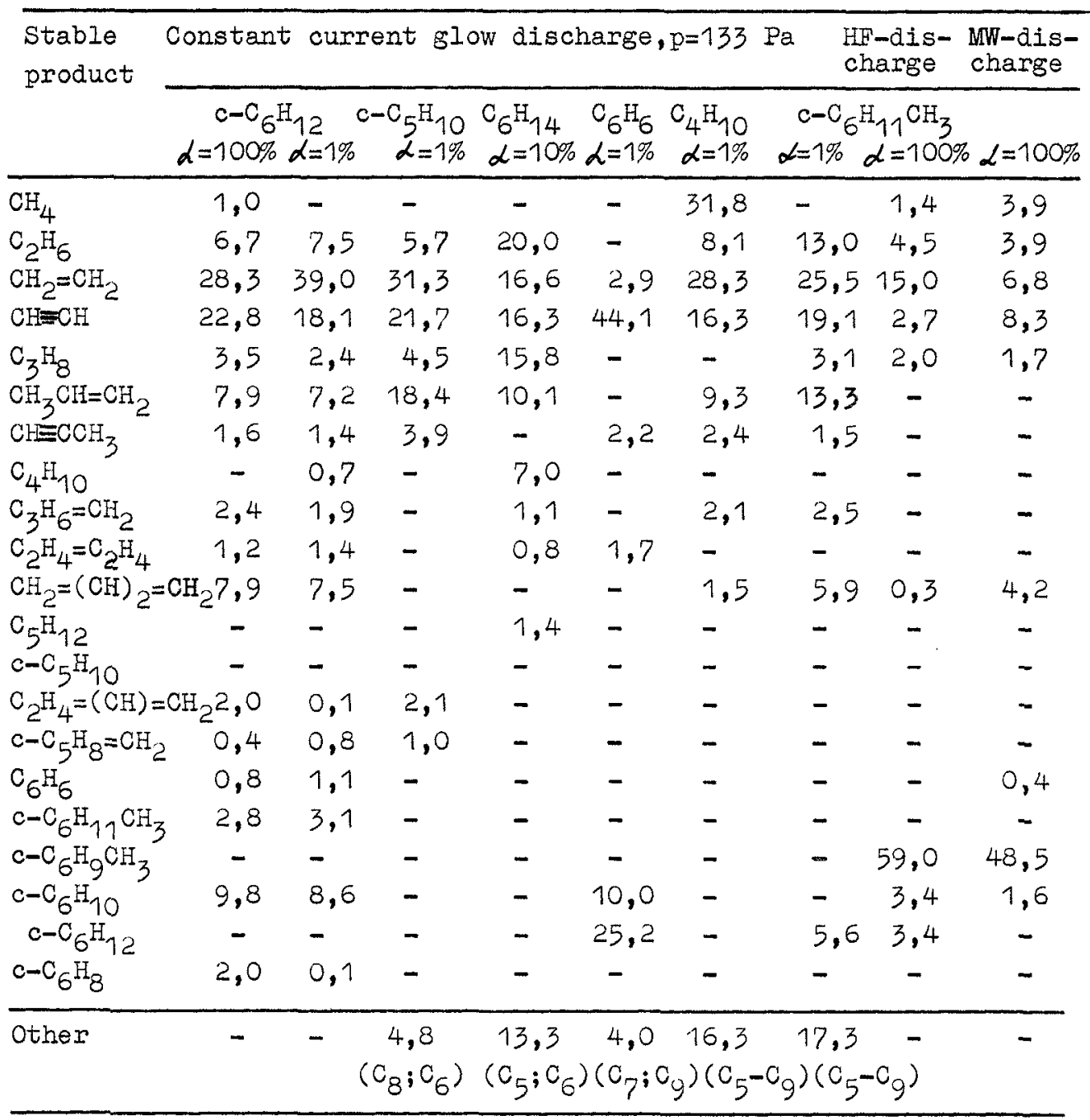


Gaseous products are main in HF and MW discharges (Table 3). Products generated due to breaking off $\mathrm{C}-\mathrm{C}$ bonds predominate among the gaseous products In dc discharges. At that time products generated due to breaking off $\mathrm{C}-\mathrm{H}$ bonds predominate among the decomposition products in HF and MW discharges, where more parts of products are gaseous ones. In earlier works (ref. 7) it had been supposed that gaseous products were generated mainly due to decay of cyclohexane rings prefaerably to stable molecular fragments of $\mathrm{C}_{2}: \mathrm{C}_{2}: \mathrm{C}_{2}$; $\mathrm{C}_{3}: \mathrm{C}_{3}$ and $\mathrm{C}_{2}: \mathrm{C}_{4}$ types.

But it is clear that decay can give radicals which being unstable particles

give risets table products as result of secondary reactions.

Determination of radicals in dischage plasmas is one of the more complex problems in studying dissociation mechanisms (Table 1).

In earlier works radicals were identified by means of optical spectra of plasmas. But this method gives certain identification as rules only for atoms and two atomic radicals and in exclusive cases for 3 -atomic radicals (ref.19) In the cases of manyatomic radicals the identification is difficult due to diffusion of spectra and hence is based on chemical proof only. It gives uncertain conclusions about type of radiating radical (Table 5). Mass-spectroscopic technique gives a certain information in the case of light hydrocarbons $\left(\mathrm{C}_{1}, \mathrm{C}_{2}\right)$, but for heavier ones difficulties of identification are very large.

Spin trapping technique was found to be the most effective one for heavy hydrocarbons. A number of substances (such as 2-methyl-2-nitrozopropane, nitrobenzene,phenyl-thret-butylnitron etc) exposed to plasma can capture the radicals giving stable substances (so-called adduct-radicals) with characteristic ESRspectra, depending on type of radicals. Exposing of spin trapping to plasma of discharge in pure argon gives no ESR-signals. In latter case surface of spin trapping positioned at $5 \mathrm{~cm}$ distance from discharge in gas flow is bombarded by excited and charged particleswhich flow is much more than in mixture of argon with hydrocarbons. Therefore only hydrocarbon radicals give ESR-signal (Fig. 7). Information on type of radicals is derived from pick to pick distance and pick intensities in ESR-spectra of adduct-radicals. The view of adduct-radical ESR-spectra is differentfrom ESR-spectra of the free radicals.

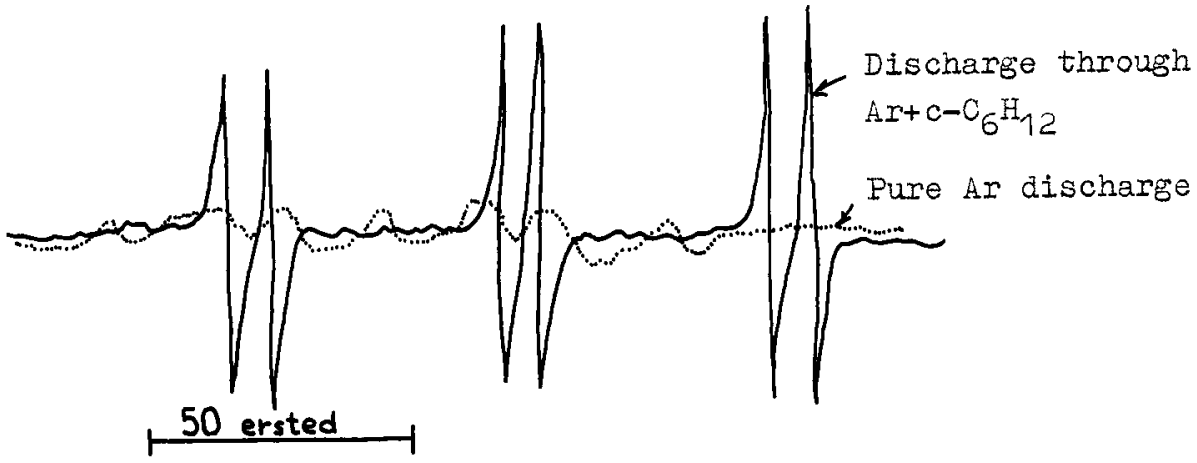

Fig. 7. ESR-spectra of adduct-radicals observed after exposition of radical trapping to discharge through mixture of $\mathrm{C}_{6} \mathrm{H}_{12}$ with argon and pure argon 
TABIE 5. Main radicals*), observed in nonequilibrium electric discharges through hydrocarbons

\begin{tabular}{|c|c|c|c|}
\hline Hydrocarbon & Observed radicals & $\begin{array}{l}\text { Measuring } \\
\text { technique }\end{array}$ & Conditions \\
\hline $\mathrm{CH}_{4}$ & $\mathrm{CH}_{3}, \mathrm{CH}_{2}, \mathrm{C}_{2} \mathrm{H}_{3}, \mathrm{C}_{2} \mathrm{H}_{5}, \mathrm{H}$ & $\begin{array}{l}\text { Mass-spec- } \\
\text { trometr }\end{array}$ & $\begin{array}{l}\text { HF-discharge, (ref.20) } \\
p=13-133 \mathrm{~Pa}\end{array}$ \\
\hline $\mathrm{CH}_{4}$ & $\begin{array}{l}\mathrm{H}, \mathrm{CH}, \mathrm{CH}_{2}, \mathrm{C}_{2}, \mathrm{C}_{3} \\
\mathrm{H}\end{array}$ & $\begin{array}{l}\text { Optical } \\
\text { spectro- } \\
\text { scopy }\end{array}$ & $\begin{array}{l}\text { Impuls dischar- } \\
\text { ge } \\
\text { Constant current } \\
\text { glow discharge (ref.6) }\end{array}$ \\
\hline $\begin{array}{l}6 \\
\mathrm{H}_{5} \mathrm{CH}_{3} \\
\mathrm{CH}_{5} \mathrm{C}_{3} \mathrm{H}_{7} \\
\mathrm{C}_{5} \mathrm{CH}_{2} \mathrm{C}_{6} \mathrm{H}_{5} \\
\mathrm{H}_{5}\left(\mathrm{CH}_{2}\right)_{2} \mathrm{C}_{6}\end{array}$ & $\begin{array}{l}\mathrm{C}_{6} \mathrm{H}_{5}(?) \\
\text { or } \\
\mathrm{C}_{6} \mathrm{H}_{5} \mathrm{CH}_{2}(?)\end{array}$ & $\begin{array}{l}\text { Optical } \\
\text { spectro- } \\
\text { scopy }\end{array}$ & $\begin{array}{l}\text { Constant current } \\
\text { glow discharge } \\
\text { through mixture } \\
\text { of heleum with } \\
1-5 \% \text { hydrocarbons } \\
p=26-200 \mathrm{~Pa} ; \\
j=1-2 \mathrm{~mA} / \mathrm{cm}^{2} \quad \text { (ref.21) }\end{array}$ \\
\hline & $\begin{array}{l}\mathrm{H}, \mathrm{CH}, \mathrm{C}_{2}, \mathrm{C}_{2} \mathrm{H}\left(\text { or } \mathrm{C}_{4} \mathrm{H}_{2}^{+}\right) \\
\mathrm{C}_{6} \mathrm{H}_{5} \mathrm{CH}_{2}(?), \mathrm{C}_{6} \mathrm{H}_{5} \mathrm{C}(?) \\
\mathrm{C}_{6} \mathrm{H}_{4}(?), \mathrm{C}_{6} \mathrm{H}_{5} \mathrm{CH}_{2}(?)\end{array}$ & $\begin{array}{l}\text { Optical } \\
\text { spectro- } \\
\text { scopy }\end{array}$ & $\begin{array}{l}\mathrm{HF} \text { and MW-dis- } \\
\text { charges }, \\
\mathrm{p}=26-266 \mathrm{~Pa} ; \\
\mathrm{W}=15-100 \mathrm{~W} \quad \text { (ref.22) }\end{array}$ \\
\hline & $\begin{array}{l}\mathrm{C}_{6} \mathrm{H}_{5} \\
\mathrm{C}_{6} \mathrm{H}_{5} \mathrm{CH}_{2}\end{array}$ & $\begin{array}{l}\text { Radical } \\
\text { trapping }\end{array}$ & HF-discharge \\
\hline $\begin{array}{l}\mathrm{C}-\mathrm{C}_{6} \mathrm{H}_{12} \\
\mathrm{c}-\mathrm{C}_{5} \mathrm{H}_{10} \\
\mathrm{C}-\mathrm{C}_{6} \mathrm{H}_{11} \mathrm{CH}_{3} \\
\mathrm{C}_{6} \mathrm{H}_{14} \\
\mathrm{C}_{6} \mathrm{H}_{6}\end{array}$ & $\begin{array}{l}\mathrm{H}, \mathrm{C}-\mathrm{C}_{6} \mathrm{H}_{11} \\
\mathrm{H}, \mathrm{C}-\mathrm{C}_{5} \mathrm{H} \\
\mathrm{H}, \mathrm{CH}_{3}, \mathrm{C}-\mathrm{C}_{6} \mathrm{H}_{11} \mathrm{CH}_{2}, \\
\mathrm{C}-\mathrm{C}_{6} \mathrm{H}_{11}, \mathrm{C}-\mathrm{C}_{6} \mathrm{H}_{10} \mathrm{CH}_{3} \\
\mathrm{C}_{6} \mathrm{H}_{13}, \mathrm{H} \\
\mathrm{C}_{6} \mathrm{H}_{5}, \mathrm{H}\end{array}$ & $\begin{array}{l}\text { Radical } \\
\text { trapping }\end{array}$ & $\begin{array}{l}\text { Constant current } \\
\text { glow discharge } \\
\text { through mixture } \\
\text { of argon with } \\
\text { hydrocarbon } \\
\alpha=1 \% ; p=133 \mathrm{~Pa} ;(\text { ref.4, } \\
\left.j=1,2 \mathrm{~mA} / \mathrm{cm}^{2} \quad 12,15\right)\end{array}$ \\
\hline $\begin{array}{l}\mathrm{C}_{4} \mathrm{H}_{10} \\
\mathrm{C}_{5} \mathrm{H}_{12}\end{array}$ & $\begin{array}{l}\mathrm{C}_{4} \mathrm{H}_{9} \\
\left(\mathrm{C}_{2} \mathrm{H}_{5}\right)_{2} \mathrm{CH}\end{array}$ & $\begin{array}{l}\text { Radical } \\
\text { trapping }\end{array}$ & $\begin{array}{l}\text { Silent dischar- } \\
\text { ge (ref.24) }\end{array}$ \\
\hline $\begin{array}{l}\mathrm{C}_{6} \mathrm{H}_{14} \\
\mathrm{c}-\mathrm{C}_{6} \mathrm{H}_{12} \\
\mathrm{C}_{7} \mathrm{H}_{16} \\
\mathrm{C}_{6} \mathrm{H}_{5} \mathrm{CH}_{3}\end{array}$ & $\begin{array}{l}\mathrm{C}_{6} \mathrm{H}_{13} \\
\mathrm{c}-\mathrm{C}_{6} \mathrm{H}_{11} \\
\mathrm{C}_{7} \mathrm{H}_{15} \\
\mathrm{C}_{6} \mathrm{H}_{5} \mathrm{CH}_{2}\end{array}$ & & \\
\hline
\end{tabular}

*) Concentrations of any other radicals are less than $20 \%$ of ones shown in the table.

It was shown by spin trapping technique that the main hydrocarbon radicals generated during decomposition are the products of breaking off hydrogen atom from rings, chains on methyl substitution group (Table 5). In the case of HF and MW discharges in benzeneproducts, ther fragmentation were observed (ref. 22). But this fact is accounted for high specific discharge power (Fig. 1,2) followed by high gas temperature and high rate of secondary reactions. The latter are responsible for the appearance of $\mathrm{C}_{2}-\mathrm{C}_{3}$-radicals in the case of methane (Table 5). Quantitative data concerning radical concentrations are 
absent because all known techniques are nonquantitative and give only relative concentration.

Analyses of data of tables (3-5) show that among gaseous products are a few which can be generated from radicals (Table 5). At first view it could be to confirm the conclusions of ref. 7 about molecular break-ap of cyclohexane rings.

To clear up this question and to study mechanism of chemical reactions special experiments were carried out with dc discharge by using isotopelabeled technique. The mixtures of protonated and deuterated cyclohexanes in ratios $9: 1$ and $1: 1$ with total concentration of $1 \%$ were introduced to argon and used a.s working gas in dc discharge. Products were analysed by chromatomass-spectrometry (ref. 4,15).

The gaseous products were shown to divide in relation with its isotopic composition to three groups.

The first group consisted of products, containing only hydrogen or only deuterium atoms: ethene $\left(\mathrm{C}_{2} \mathrm{H}_{4} ; \mathrm{C}_{2} \mathrm{D}_{4}\right)$; acetylene $\left(\mathrm{C}_{2} \mathrm{H}_{2} ; \mathrm{C}_{2} \mathrm{D}_{2}\right)$; methylencyclopentane $\left(c-C_{5} \mathrm{H}_{8}=\mathrm{CH}_{2} ; c-\mathrm{C}_{5} \mathrm{D}_{8}=\mathrm{CD}_{2}\right)$; cyclohexene $\left(c-\mathrm{C}_{6} \mathrm{H}_{10} ; c-\mathrm{C}_{6} \mathrm{D}_{10}\right) ; 1,3$ and 1,4 cyclohexadienes $\left(c-\mathrm{C}_{6} \mathrm{H}_{8} ; \mathrm{c}-\mathrm{C}_{6} \mathrm{D}_{8}\right)$; benzene $\left(\mathrm{C}_{6} \mathrm{H}_{6} ; \mathrm{C}_{6} \mathrm{D}_{6}\right)$.

The second group consisted of products having comparable output all partially substituted proto-deutero compounds: ethane and propane (Table 6).

TABIE 6. Isotopic abundance of cyclohexane decomposition products included in 2 d and 3 d group, see text: $\alpha=1 \% ; j=2,4 \mathrm{~mA} / \mathrm{cm}^{2}$; $\mathrm{p}=133 \mathrm{~Pa}$. Sum of registrated isotopic abundance of every product is equal to $100 \%$. Isotopic composition of initial mixture $c-\mathrm{C}_{6} \mathrm{H}_{12}: c-\mathrm{C}_{6} \mathrm{D}_{12}=\mathrm{B}: 1$

\begin{tabular}{|c|c|c|c|c|c|c|c|c|}
\hline \multirow[t]{2}{*}{ Product } & \multirow[t]{2}{*}{ Isotop } & \multicolumn{2}{|c|}{ Abundance, $\%$} & \multirow[t]{2}{*}{ Product } & \multirow[t]{2}{*}{ Isotop } & \multicolumn{3}{|c|}{ Abundance,\% } \\
\hline & & $B=1$ & $B=9$ & & & & $B=1$ & $B=9$ \\
\hline \multirow[t]{4}{*}{ Ethane } & & 12 & 5 & \multirow{8}{*}{$\begin{array}{l}\text { Butene-1 } \\
\text { (Butene-2 } \\
\text { numbers } \\
\text { in bra- } \\
\text { ckets) }\end{array}$} & \multirow{8}{*}{$\begin{array}{l}\mathrm{C}_{4} \mathrm{D}_{8} \\
\mathrm{C}_{4} \mathrm{D}_{7} \mathrm{H} \\
\mathrm{C}_{4} \mathrm{D}_{6} \mathrm{H}_{2} \\
\mathrm{C}_{4} \mathrm{D}_{5} \mathrm{H}_{3} \\
\mathrm{C}_{4} \mathrm{D}_{4} \mathrm{H}_{4} \\
\mathrm{C}_{4} \mathrm{D}_{3} \mathrm{H}_{5} \\
\mathrm{C}_{4} \mathrm{D}_{2} \mathrm{H}_{6} \\
\mathrm{C}_{4} \mathrm{DH}_{7} \\
\mathrm{C}_{4} \mathrm{H}_{8}\end{array}$} & 16 & $(32)$ & $2(4)$ \\
\hline & & 18 & 7 & & & 22 & $(19)$ & $7(5)$ \\
\hline & & 28 & 22 & & & 4 & $(1)$ & $4(3)$ \\
\hline & & 42 & 66 & & & 4 & (2) & $2(6)$ \\
\hline \multirow[t]{7}{*}{ Propane } & & 12 & 1 & & & 5 & $(0)$ & $4(0)$ \\
\hline & & 13 & 4 & & & 5 & $(1)$ & $4(2)$ \\
\hline & $\mathrm{C}_{3} \mathrm{D}_{6} \mathrm{H}_{2}$ & 9 & 7 & & & 17 & $(21)$ & $22(10)$ \\
\hline & & 12 & 12 & & & 22 & $(24)$ & $55(75)$ \\
\hline & & 14 & 10 & \multirow{7}{*}{$\begin{array}{l}\text { Methyl- } \\
\text { cyclo- } \\
\text { hexane }\end{array}$} & \multirow{3}{*}{\multicolumn{2}{|c|}{$\begin{array}{l}\mathrm{C}-\mathrm{C}_{6} \mathrm{D}_{11} \mathrm{CD}_{3} \\
\mathrm{C}-\mathrm{C}_{6} \mathrm{D}_{11} \mathrm{CD}_{2} \mathrm{H} \\
\mathrm{C}-\mathrm{C}_{6} \mathrm{D}_{11} \mathrm{CDH}_{2}\end{array}$}} & 24 & 24 \\
\hline & $\mathrm{C}_{3} \mathrm{D}_{2} \mathrm{H}_{6}$ & 15 & 22 & & & & 8 & 3 \\
\hline & $\mathrm{C}_{3} \mathrm{DH}_{7}$ & 17 & 36 & & & & 9 & 6 \\
\hline \multirow[t]{4}{*}{ Propene } & $\mathrm{C}_{3} \mathrm{D}$ & 51 & 32 & & & & $\begin{array}{l}10 \\
11\end{array}$ & $\begin{array}{r}18 \\
2\end{array}$ \\
\hline & $\mathrm{C}_{3} \mathrm{D}_{5} \mathrm{H}$ & 44 & 51 & & $\mathrm{c}-\mathrm{C}_{6} \mathrm{H}_{11} \mathrm{CI}$ & $\mathrm{O}_{2} \mathrm{H}$ & 12 & 5 \\
\hline & $\mathrm{C}_{3} \mathrm{D}_{4} \mathrm{H}_{2}$ & 0 & 11 & & $c-\mathrm{C}_{6} \mathrm{H}_{11} \mathrm{CI}$ & $\mathrm{OH}_{2}$ & 11 & 6 \\
\hline & $\mathrm{C}_{3} \mathrm{D}_{3} \mathrm{H}_{3}$ & 5 & 6 & & $\mathrm{c}-\mathrm{C}_{6} \mathrm{H}_{11} \mathrm{Cr}$ & & 15 & 37 \\
\hline
\end{tabular}


The third sroup

consisted of products having unequal isotope outputs:methylcyclohexane, propylene and butene (Table 6).

Direct primary decay of cyclohexane can give only products of the group. Relative output of various products of this group depends on initial hydrocarbon concentration in mixture, current density and gas pressure (Fig. $8 a, b, c$ ).
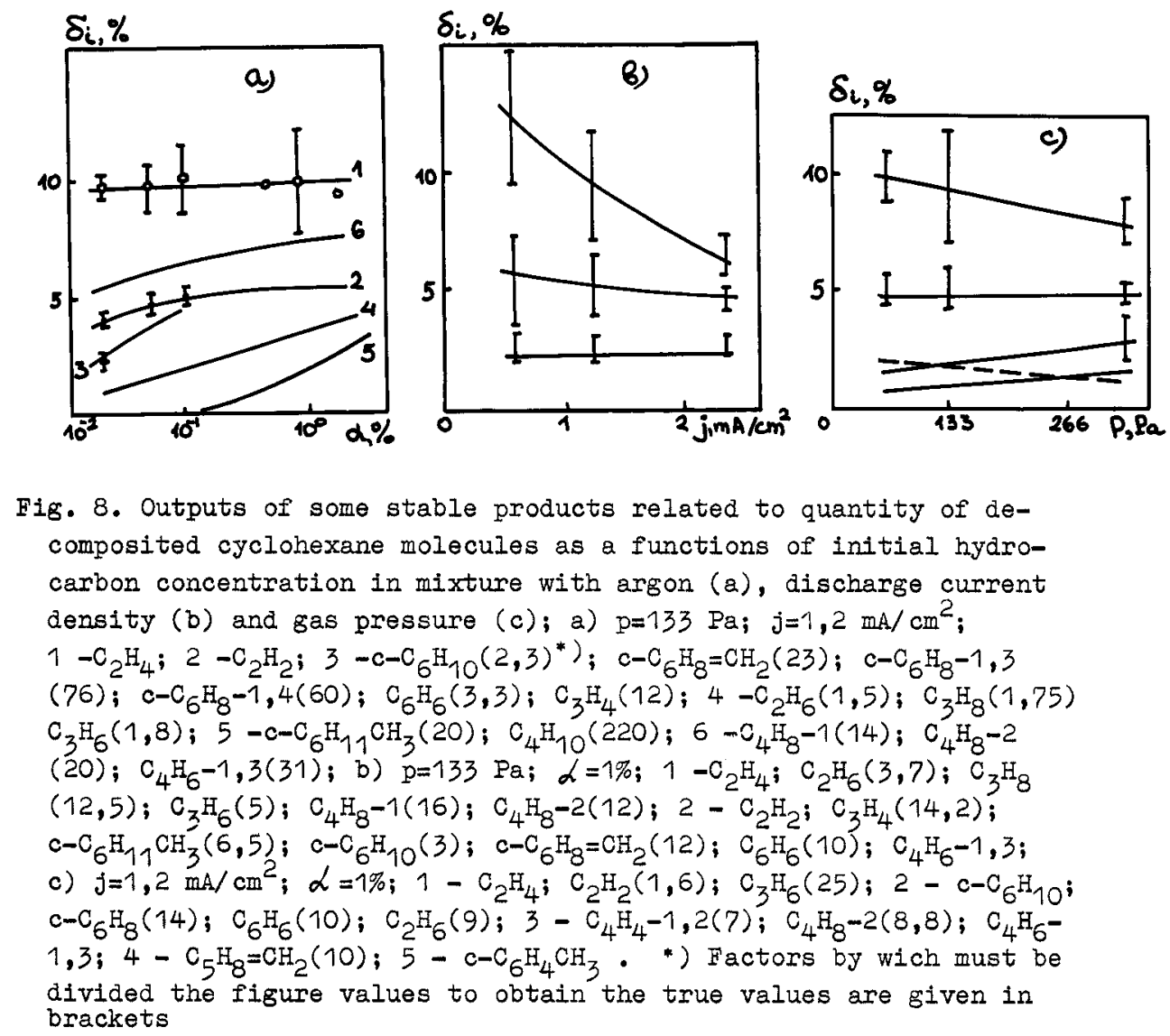

A number of them could be generated by means of consecutive dehydrogenation of primary products during their collisions with hydrogen atoms and electrons. In these cases their relative output could be increased by increasing current density because of increase of concentration of atomic hydrogen and electrons. But relative products outputs of first group were decreased or invariable as observed with current density increases (Fig. 8b). This fact excludes significant contributions gconsecutive dehydrogenation reactions. The same is true about other reactions of dehydrogenation by collisions with other radicals as generated in primary decay. In both cases relative outputs of these products must be increased with $\alpha$. Indeed some increase of output was observed for $\mathrm{C}_{2} \mathrm{H}_{2}, c-\mathrm{C}_{6} \mathrm{H}_{10}, c-\mathrm{C}_{6} \mathrm{H}_{8}$ and $\mathrm{C}_{5} \mathrm{H}_{8}=\mathrm{CH}_{2}$ in the range of small $\alpha$ (Fig. $8 \mathrm{a}$ ) and with increase of pressure (Fig. $8 \mathrm{C}$ ). But this dependence must be more sharp in the case of consecutive reactions, namely $\delta_{i} \sim \alpha^{2}$ and $\delta_{i} \sim p^{2}$. Weak dependence of relative outputs on $\alpha, p$ and current density exclude entirely contribution of consecutive dehydrogenation. Therefore all products of first group are direct products of primary decay of excited cyclohexane molecules by electron impacts $(1,2)$. Dependence of 
various product outputs on discharge parameters and $\alpha$ is accounted for different path of excitation. By small $\alpha$ collisions of cyclohexane with metastable argon atoms (reaction 2) give significant contribution, but by larger $\alpha(\alpha \geq 0,1 \%)$ impacts of electrons give main contribution. Appearance potentials of various products are different as the decay takes place from various levels followed by variation of products composition with elect-

ron energy.

Then primary decay of excited cyclohexane takes place according to the scheme : breaking of $\mathrm{C}-\mathrm{H}$ bonds

$$
\begin{aligned}
\left(c-\mathrm{C}_{6} \mathrm{H}_{12}\right)^{*} \longrightarrow & \longrightarrow \mathrm{c}-\mathrm{C}_{6} \mathrm{H}_{11}+\mathrm{H} \\
& =\mathrm{c}_{6} \mathrm{C}_{10}+\mathrm{H}_{2}(2 \mathrm{H}) \\
& \mathrm{c}-\mathrm{C}_{6} \mathrm{H}_{8}+2 \mathrm{H}_{2} \\
& \mathrm{c}-\mathrm{C}_{6} \mathrm{H}_{6}+\mathrm{H}_{2}^{2} .
\end{aligned}
$$

Strong isotopic effect was observed for benzene. Its output due to decay of $c-C_{6} D_{12}$ was at times higher than in the case of $c-C_{6} H_{12}$. This can be explained by strong influence of mass on the complex decay (12).

Breaking of $\mathrm{C}-\mathrm{C}$ bonds of types $\mathrm{C}_{2}: \mathrm{C}_{2}: \mathrm{C}_{2}$ :

and types $\mathrm{C}_{2}: \mathrm{C}_{4}$

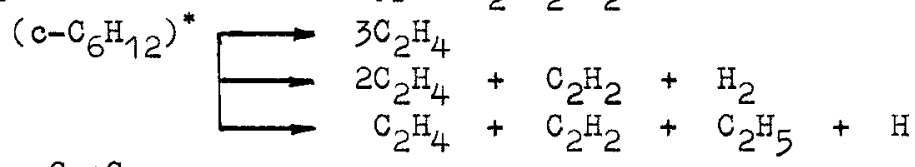

$$
\left(\mathrm{c}-\mathrm{C}_{6} \mathrm{H}_{12}\right)^{*} \longrightarrow \mathrm{C}_{4} \mathrm{H}_{6}+\mathrm{C}_{2} \mathrm{H}_{4}+\mathrm{H}_{2}
$$

and breaking off one $\mathrm{C}-\mathrm{C}$ bond followed by isomerization of biradical and escaping of $\mathrm{H}_{2}$

$$
\left(\mathrm{c}-\mathrm{C}_{6} \mathrm{H}_{12}\right)^{*} \longrightarrow \mathrm{C}_{6} \mathrm{H}_{12} \longrightarrow \mathrm{c}_{5} \mathrm{C}_{5} \mathrm{H}_{8}=\mathrm{CH}_{2}+\mathrm{H}_{2} \cdot
$$

The first group of products includes possibly an allen. Its isotopic composition was not studied. But depedence of allen output on discharge parameters is the same as observed for products of first group (Fig. 8a,b,c). Hence it is generated due to reaction

$$
\left(\mathrm{c}-\mathrm{C}_{6} \mathrm{H}_{12}\right)^{*} \longrightarrow \mathrm{C}_{3} \mathrm{H}_{4}+\mathrm{C}_{3} \mathrm{H}_{7}+\mathrm{HI}
$$

which is only one example of ring distribution of types $C_{3}: C_{3}$ with appearance of stable products. Decay of type $\mathrm{C}: \mathrm{C}_{5}$ was not observed.

Reaction scheme (9-18) differs significantly from supposeã earlier (7), according to which main decay reactions give saturated alkanes directly (ethane, propane, butane). Isotopic abundance of alkanes with nearly equal outputs of all protonated-deuterated products as observed (Table 5) is the proof of generation of thesealkanes during secondary reactions most possibly with participation of radicals.

Generation of radicals can occur during primary decay of excited molecules:

$$
\begin{aligned}
\left(c-\mathrm{C}_{6} \mathrm{H}_{12}\right)^{*} \longrightarrow \mathrm{C}_{2} \mathrm{H}_{5}+\mathrm{C}_{4} \mathrm{H}_{7} \\
\longrightarrow \mathrm{C}_{2} \mathrm{H}_{3}+\mathrm{C}_{4} \mathrm{H}_{9} \\
\longrightarrow \mathrm{C}_{3} \mathrm{H}_{7}+\mathrm{C}_{3} \mathrm{H}_{5} .
\end{aligned}
$$

Direct experiments confirmed possible appearance of stable products and radicals with simultaneous escaping of several hydrogen atoms and molecules and simultaneous breaking off several $\mathrm{C}-\mathrm{C}$ and $\mathrm{C}-\mathrm{H}$ bonds by direct impact of electrons with molecules. For example, following products were observed as result of butane dissociation: $\mathrm{CH}_{2}(13,5 \pm 1) ; \mathrm{CH}_{3}(9,0 \pm 0,5) ; \mathrm{CH}_{4}(11,0 \pm 0,5)$; $\mathrm{C}_{2} \mathrm{H}_{2}(13,0 \pm 1,0) ; \mathrm{C}_{2} \mathrm{H}_{3}(13,0 \pm 1,0) ; \mathrm{C}_{2} \mathrm{H}_{5}(10,5 \pm 1,0) ; \mathrm{C}_{3} \mathrm{H}_{3}(14,0 \pm 2,0) ; \mathrm{C}_{3} \mathrm{H}_{4}(14,0 \pm$ $2,0) ; \mathrm{C}_{3} \mathrm{H}_{5}(12,5 \pm 1,0) ; \mathrm{C}_{4} \mathrm{H}_{2}(15,0 \pm 1,0) ; \mathrm{C}_{4} \mathrm{H}_{3}(14,0 \pm 1,0) ; \mathrm{C}_{4} \mathrm{H}_{4}(14,5-1,0) ; \mathrm{C}_{4} \mathrm{H}_{5}$ 
$(12,0 \pm 2,0) ; \mathrm{C}_{4} \mathrm{H}_{6}(12,0 \pm 1,0)$. Appearance potentials as measured are shown in brackets (ref. 25).

The products of the third group are generated as result of secondary reactions of primary decay products. Their unsubstituted parts are products of primary decay. They are connected with radicals, generated in primary decay and/ or in secondary reactions.

Methylcyclohexane is one of most interesting products of this group. It has entirely protonated or entirely deuterated rins connected with methyl group and output of products with all partly deuterated and protonated methy groups are nearly equal (Table 6). Hence it can be generated by two paths: recombination of radicals

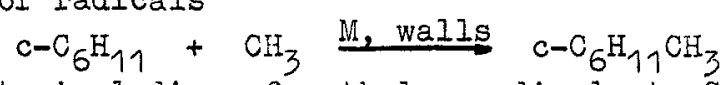

or due to including of methylene radicals to $\mathrm{C}-\mathrm{H}$ - bond

$$
\mathrm{c}-\mathrm{C}_{6} \mathrm{H}_{12}+\mathrm{CH}_{2} \longrightarrow \mathrm{C}_{6} \mathrm{C}_{6} \mathrm{H}_{11} \mathrm{CH}_{3} \text {. }
$$

In the latter case $c-\mathrm{C}_{6} \mathrm{H}_{11} \mathrm{CH}_{2} \mathrm{C} ; \mathrm{C}-\mathrm{C}_{6} \mathrm{D}_{11} \mathrm{CH}_{2} \mathrm{C}$ and $\mathrm{C}-\mathrm{C}_{6} \mathrm{D}_{11} \mathrm{CD}$ H must not be served. It is contrary to data (Table 6 ). Hence the reaction (23) gives no contribution and generation is due to recombination of radicals (22). Methyl radicals must be nearly equally deuterated - protonated. Such radicals can explain generation of ethane

$$
\mathrm{CH}_{3}+\mathrm{CH}_{3} \stackrel{\mathrm{M} \text { Walls }}{-} \mathrm{C}_{2} \mathrm{H}_{6}
$$

and propane also

$$
\mathrm{CH}_{3}+\mathrm{C}_{2} \mathrm{H}_{5} \stackrel{\mathrm{M} \text {, walls }}{\mathrm{C}_{3} \mathrm{H}_{8}}
$$

with their isotopic composition (Table 6).

Butenes and propylene are generated most probably due to disproportion reactions

$$
\begin{aligned}
& \mathrm{C}_{3} \mathrm{H}_{7}+\mathrm{CH}_{3} \longrightarrow \mathrm{C}_{4} \mathrm{H}_{8}+\mathrm{H}_{2} \\
& \mathrm{C}_{2} \mathrm{H}_{5}+\mathrm{CH}_{3} \longrightarrow \mathrm{C}_{3} \mathrm{H}_{6}+\mathrm{H}_{2}
\end{aligned}
$$

and radical recombination

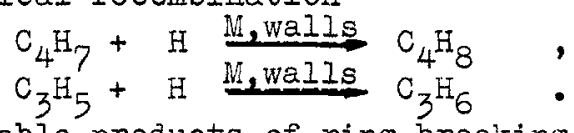

Thesestable products of ring breaking are $\mathrm{C}_{2}: \mathrm{C}_{2}: \mathrm{C}_{2}$ type $\left(\mathrm{C}_{2} \mathrm{H}_{4}, \mathrm{C}_{2} \mathrm{H}_{2}\right)$, one $\mathrm{C}-\mathrm{C}$ bond $\left(\mathrm{C}_{5} \mathrm{H}_{8}=\mathrm{CH}_{2}\right)$ and breaking of several $\mathrm{C}-\mathrm{H}$ bonds $\left(\mathrm{C}_{6} \mathrm{H}_{10}, \mathrm{C}_{6} \mathrm{H}_{8}, \mathrm{C}_{6} \mathrm{H}_{6}\right)$ are generated during primary decay of excited cyclohexane molecules. The ring breaking of $\mathrm{C}_{4}: \mathrm{C}_{2}\left(\mathrm{C}_{4} \mathrm{H}_{6}\right)$ and $\mathrm{C}_{3}: \mathrm{C}_{3}\left(\mathrm{C}_{3} \mathrm{H}_{4}\right)$ types makes a small contribution. Total output of gaseous stable products due to direct breaking of $\mathrm{C}-\mathrm{C}$ bonds is less than $7,5 \%$ and of $\mathrm{C}-\mathrm{H}$ bonds is less $2,5 \%$. Output of gaseous products generated due to secondary reaction, with participation of cyclohexyl radical (nain radical in plasma) namely methylcyclohexane is less that $0,4 \%$. outputs of gaseous products of recombination of other radicals are one order value larger in spite of the other radicals concentrations as measured are at 5 times less than cyclohexyl one. This allows to suppose that cyclohexyl radicals take part in building of solid products on the walls.

\section{MECHANISMS OF DEPOSITION OF FILMS}

The solid polymeric film is the main product of decomposition of all studied hydrocarbons in dc discharge (Table 3). Rate of film deposition increases proportionally to cyclohexane concentration in initial mixtures under condition of constancy of all other plasma parameters including the charged particle flow to surface. Hence deposition does not occur due to put into film of cyclohexane ionsbeing the main ions in plasma at $\alpha>0,1 \%$. To study con- 
tribution in deposition of unsaturated hydrocarbons generated due to hydrocarbon decomposition a numberofexperiments were carried out - the

mixtures of deuterated cyclohexane and protonated ethenewere used by total concentration of hydrocarbons in argon equals 1\%. Deposited films do not contain the hydrogen if ethene addition was equal to one generated due to decomposition of cyclohexane in mixture with argon (Table 3). The hydrogen was observed in films only by increasing the ethene concentration in mixture to ten times ( $3 \% \mathrm{C}_{2} \mathrm{H}_{4}+1 \% \quad c-\mathrm{C}_{6} \mathrm{D}_{12}+96 \% \mathrm{Ar}$ ) (ref. 4,5,15). Hence the unsaturated in plasma do not give significant contribution to film deposition.

The most probable mechanism of film deposition as studied contains building in of heavy radicals generated due to breaking of $\mathrm{C}-\mathrm{H}$ bonds. Building up is due to recombination with free bonds on surface generated due to its bombardment by energetic plasma particles. The latter gives rise to futher destruction of bonded radicals, atomic hydrogen and light radical desorption $\left(\mathrm{CH}_{2}, \mathrm{CH}_{3}\right.$ ...). Free bonds generated asa result recombine one with another giving generation of cross links and double bonds, and with radicals coming from plasma giving films growth.

Recombination with hydrogen atoms leads to decay of free bonds. This reactions explain mixed isotopic composition of light radicals in plasma, because hydrogen is main gaseous product of hydrocarbons decomposition.

Such a mechanism is confirmed by data observed using benzene. In this case film contained aromatic structures - phenyl, bi- and three- phenyl fragments. Concentrations of the latter were diminished with increasing bombardment intensity by means of decreasing of benzene concentration in initial mixture, or additional treatment growed films by pure argon plasma.

Main role was shown in free bonds generation to play lons by using mixture of methane with rare gases. Ion building in films is not significant as substitution of hydrocarbon ions by xenon ones do not influence the rate of film growth (ref. 13,26). Hence growth is due to hydrocarbon radicals. Cyclohexyl radicals built into film in cyclohexane being main products of primary decomposition and give rise to very low outputs of gaseous products.

\section{CONCLUSION}

This application of quantitative method to studying of chemical reaction nechanism in nonequilibrium plasma diagnostic (ref, 1) allows to find most probable paths of gaseous and solid products generation during decomposition of hydrocarbons in dc discharge plasma (ref. 4,5,15). The mechanism differs significantly from those proposed earlier (ref. 7,21,22 etc). The main difference shown here is that primary decay gives rise to radicals even in the reactions generating stable products too. Most decays are due to breaku of $\mathrm{C}-\mathrm{H}$ bonds followed by solid film deposition as result of radical recombination on surfaces. Breaking of $\mathrm{C}-\mathrm{C}$ bonds gives rise to gaseous products. Primary decomposition reactions are decays of electronically excited hydrocarbon molecules. Excitation is made by collisions with electrons and meta-stable atoms.

Role of ions in decomposition reactions is negligible. They play large role in solid product deposition rate and composition due to bombardment of surfaces. 
The mechanism is valid in glow discharges by low pressures $(p<500 \mathrm{~Pa})$ and current densities $\left(j<10 \mathrm{~mA} / \mathrm{cm}^{2}\right)$. Under other conditions for example in discharges with higher specific poer and pressure particularly in HF and MW discharges a new detailed analyses is needed based on the quantitative diagnostics of plasma.

\section{REFERENCES}

1. D.I.Slovetsky, Chemical reaction mechantsms under nonequilibrium plasma conditions, Moskow, Science, 311p. (1980) (in Russian).

2. L.S.Polak, Nonequilibriume chemical kinetics and its application, Moskow, Science, 248p. (1979) (in Russian).

3. Ju.A.Ivanov, I.N.Karabashev, L.S.Polak, High energy chemistry, 13, 75-79, (1979) (in Russian; the journal is translated in English).

4. G.A.Alekperov, L.S.Polak, D.I.Slovetsky. In: Syntheses in low temperature plasma, Moskow, Science, $44-46$ (1980) (in Russian).

5. G.A.Alekperov, I.S.Polak, D.I.Slovetsky, High energy chemistry, 11, N6, 457 (1977); 12, 379-38 (1978); 13, N1, 85-90 (1979) (in Russian; the Journal is translated in English).

6. Ju.A.Ivanov, I.V.Soldatova, I.I.Epshtaine, ibid, 19, N5, 465-470 (1985).

7. H.Schïler, G.Arnold, Z.Naturforsch, 12a, 670-675 (1962); 18a, 604-607 (1963); 20a, 435-441 (1965).

8. S.Klagge, Beitr.Pla.smaphys. , 15, 309-317 (1975).

9. R.Winkler, J.Wilhelm, ibid, 8, 403-422 (1968); 11, 159-1.78 (1971).

10. V.E.Galtsev, Ju.A.Ivanov, N.M.Ritova et all. Proc. 6-th Allunion Conference on Physics of low temperature Plasma, Leningrad, USSR, 1, 132-134 (1983) (in Russian).

11. M.Deutsch, H.Sabadil, E.W.Görse, Beiträge aus der Plasmaphys., 15, 183190 (1975).

12. G.A.Alekperov, V.E.Zubarev, L.S.Polak, D.I.Slovetsky, High energy chemistry, 13, N2, 188-192 (1979) (in Russian; the journal is translated in English).

13. Ju.A.Ivanov, I.V.Soldatova. In: Physical and Chemical Processes in low temperature plasma, Moskow, Inst. of Petrochem. Syntheses Academy of Sclences of USSR, 5-54 (1985).

14. I.G.Piper, J.E.Velazco, D.W.Setser, J.Chem.Phys., 59, N6, 3323-3340 (1973).

15. D.I.Slovetsky. In: Chemistry of Plasma, Moskow, Atompress, N8, 189-229 (1981) (in Russian).

16. D.I.Slovetsky. Ibid, N1, 190-193 (1974). Int.J.Radiat. Phys.Chem., 8 , 257-282 (Pergamon Press, Great Britain).

17. P.Capezutto, F.Cramarossa, R.D'Agostino et all, Beitr. Plasmaphys., 17, 205-220 (1977).

18. D.I.Slovetsky, P.A.Sargeev, Chem.Review, 25(2), 231 (1983).

19. G.Herzberg, The Spectra and Structures of Simple free Radicals, Cornell Univ.Press., Ithaca, Lond. (1971).

20. G.Smolinsky, M.J.Vasile, Int.J.Mass.Spectrom.Ion.Phys., 18, 179-192 (1975).

21. H.Schüler, I.Reinbeck, Spectrochemica Acta, $\underline{6}, 288-301$ (1954).

22. M.Durval, A.Theoret, J.Appl. Polymer Sci., 17, 527-537 (1973).

23. S.Kikkawa, N.Nomura, S.Morita et all, Chem.Lett. (Chem.Soc.Japan), 10, 1337-1340 (1974).

24. D.B.Hibbert, J.B.Robertson, M.J.Perkins, J.Chem.Soc.Faraday Transact. 1, 23, 1499-1508 (1971).

25. A.Nichaus, Z.Naturforsch., 22a, 690-700 (1967). 